and/or low monitoring by GPs. Early treatment was not being initiated despite a high prevalence of CMs. Efforts must be undertaken to improve gout management, avoid clinical inertia, and reduce the individual and societal burden of gout.

\begin{tabular}{|c|c|c|c|c|}
\hline & France & Italy & Spain & UK \\
\hline Total diagnosed patients, $\mathbf{n}$ & 736,352 & 642,063 & 523,592 & 441,505 \\
\hline Crude prevalence $(\%)$ & 1.1 & 1.1 & 1.1 & 0.7 \\
\hline Treated patients, n (\%) & $\begin{array}{c}397,689 \\
(54.0)\end{array}$ & $\begin{array}{c}311,688 \\
(48.5)\end{array}$ & $\begin{array}{c}365,030 \\
(69.7)\end{array}$ & $\begin{array}{c}244,899 \\
(55.5)\end{array}$ \\
\hline $\begin{array}{l}\text { sUA measurement recorded in the } \\
\text { year (\%) }\end{array}$ & 19.9 & 56.4 & 39.5 & 40.3 \\
\hline Mean sUA, mg/dL & 6.5 & 8.1 & 6.7 & 6.5 \\
\hline \multicolumn{5}{|c|}{ Achieved sUA goal (among patients with sUA measurement recorded in the year) (\%) } \\
\hline$<6.0 \mathrm{mg} / \mathrm{dL}$ & 45.6 & 26.6 & 37.9 & 41.9 \\
\hline$\geq 6.0-<9.0 \mathrm{mg} / \mathrm{dL}$ & 44.4 & 47.8 & 47.2 & 50.3 \\
\hline$\geq 9.0 \mathrm{mg} / \mathrm{dL}$ & 9.9 & 25.6 & 14.8 & 7.7 \\
\hline \multicolumn{5}{|l|}{ Treatment (\%) } \\
\hline Allopurinol & 57.4 & 6.5 & 23.4 & 23.0 \\
\hline$<300 \mathrm{mg}$ & 15.7 & 43.9 & 15.3 & 13.2 \\
\hline $300 \mathrm{mg}$ & 0.5 & 0.1 & 0.1 & 2.8 \\
\hline \multicolumn{5}{|l|}{$>300 \mathrm{mg}$} \\
\hline Febuxostat & 28.2 & 14.2 & 1.0 & 2.0 \\
\hline Second-line treatment (\%) & 15.9 & 13.4 & 1.9 & 4.3 \\
\hline Average days on treatment, $\mathrm{n}$ & 265 & 209 & 218 & 247 \\
\hline Comorbidities present (\%) & 86.1 & 93.6 & 96.8 & 78.8 \\
\hline
\end{tabular}

Disclosure of Interests: Frederic Lioté Grant/research support from: institutional grants from Grunenthal, Ipsen Pharma/Menarini, Novartis, SOBI for the European Crystal Network Workshops, Consultant for: Grunenthal, Novartis, Ravi Karra Employee of: Grunenthal, Prashanth Kandaswamy Employee of: Grunenthal, Abhishek Abhishek Grant/research support from: AstraZeneca and Oxfordlmmunotech, Grant/research support from: AstraZeneca and Oxford Immunotech, Speakers bureau: Menarini pharmaceuticals, Speakers bureau: Menarini pharmaceuticals, Carlo Alberto Scirè: None declared, Fernando Perez-Ruiz Grant/research support from: Cruces Rheumatology Association, Consultant for: Grunenthal, Menarini, Horizon, Speakers bureau: Menarini, Grunenthal; Spanish foundation for rheumatology

DOI: 10.1136/annrheumdis-2019-eular.2868

\section{SAT0434 A TRANSIENT DECREASE IN SERUM URATE CHANGES THE CLINICAL TRAJECTORY OF SUBJECTS WITH ADVANCED GOUT}

Michael H. Pillinger ${ }^{1}$, Theodore Fields ${ }^{2}$, Anthony $\mathrm{Yeo}^{3}$, Peter Lipsky ${ }^{4} .{ }^{1} N Y U$ Langone Medical Center, New York, United States of America; ${ }^{2}$ Hospital for Special Surgery, New York, United States of America; ${ }^{3}$ Horizon Pharma, Lake Forest, United States of America; ${ }^{4}$ AMPEL BioSolutions, LLC, Charlottesville, United States of America

Background: The standard approach to monitor subjects with gout is to measure serum urate. The assumption is that the signs and symptoms of disease will improve if serum urate is maintained below the target level of $6 \mathrm{mg} / \mathrm{dL}$. However, there has been little emphasis on whether lowering urate transiently would have a prolonged impact on the clinical manifestations of advanced gout.

Objectives: Assess the clinical benefit in patients with advanced gout who had transient lowering of serum urate resulting from treatment with pegloticase, a pegylated recombinant uricase.

Methods: A post hoc analysis was carried out using the results from two randomized controlled trials (RCTs) of 6 months duration to assess the efficacy of treatment with $8 \mathrm{mg}$ of pegloticase every 2 weeks (q2w) ${ }^{1}$. Serum urate was measured before each infusion and the serum urate area under the curve (AUC) was calculated as described ${ }^{2}$ for the first and second three-month periods of time in the RCTs. The following clinical outcomes were assessed: gout flares, tophus reduction, patient global assessment (PtGA), tender and swollen joints (TJC and SJC), pain measured with a 100-mm visual analog scale (VAS) and a variety of patient reported outcomes (36-Item Short Form Health Survey [SF-36] Physical Component Score [PCS] and Arthritis-Specific Health Index Score [ASHIS]).

Results: The analysis included 85 subjects treated with q2w pegloticase and 43 patients who received placebo. Of the 85 pegloticase-treated subjects, 49 had only a transient decrease in serum urate owing to the development of anti-pegloticase antibodies. The mean length of time these subjects experienced a serum urate $<6 \mathrm{mg} / \mathrm{dL}$ was approximately 6 weeks $^{3}$. Despite the transient reduction in serum urate, the serum urate AUC for the first and second 3 months of the RCTs was significantly $(p=0.008)$ decreased compared to placebo-treated subjects. However, it was significantly $(p<0.0001)$ less reduced compared with those with persistent urate lowering throughout the 6 month RCTs (Table 1). Results for both the subjects with persistent and transient lowering of serum urate to $<6 \mathrm{mg} / \mathrm{dL}$ indicated significant reduction in tophi and improvements from baseline in PtGA, TJC, SJC, pain, and ASHIS after 6 months of the RCT. No significant improvements were observed in the patients who received placebo.

\begin{tabular}{lcc}
\multicolumn{3}{l}{ Table 1 Serum Urate Area Under the Curve in Subjects Treated with Pegloticase or Placebo } \\
\cline { 2 - 3 } Treatment & Mean $( \pm \mathrm{SD})$ Serum Urate Area Under the Curve $(\mathrm{mg} / \mathrm{dL} \cdot \mathrm{hr})$ \\
\hline Placebo & $21,093.0 \pm 3,990.1$ & Month $3-6$ \\
Transient Responders & $14,361.2 \pm 8,517.3$ & $16,665.8 \pm 3,462.0$ \\
Persistent Responders & $2,540.1 \pm 2,132.8$ & $338.9 \pm 1,137.9$
\end{tabular}

Transient responders versus placebo, first 3 months, $p<0.0001$, second 3 months, $p=0.008$ Persistent responders versus placebo for months $0-3$ and months $3-6, p<0.0001$ Persistent responders versus transient responders for months $0-3$ and months $3-6, p<0.000=$

Conclusion: A transient reduction in serum urate resulting from pegloticase therapy can result in significant clinical benefit lasting through the 6 months of the RCTs. These results suggest that transient lowering of urate can alter the trajectory of the clinical manifestations of advanced gout. Moreover, estimates of serum urate AUC may be more helpful in assessing the impact of urate lowering therapy than individual measurements of serum urate.

\section{REFERENCES}

[1] Sundy, JS, et al. JAMA. 2011; 306:711

[2] Mandell, BF, et al. Arthritis Research Ther. 2018; 20:286

[3] Lipsky, PE, et al. Arthritis Res Ther. 2014; 16:R60

Disclosure of Interests: Michael H. Pillinger Consultant for: Horizon Pharma, SOBI, Theodore Fields Consultant for: Horizon Pharma, Anthony Yeo Employee of: Horizon Pharma, Peter Lipsky Consultant for: Consulting fees from Horizon Pharma

DOI: 10.1136/annrheumdis-2019-eular.2905

\section{SAT0435 MANAGEMENT OF ADVANCED GOUT: A CLAIMS- BASED ANALYSIS FROM THE UNITED STATES}

N. Lawrence Edwards ${ }^{1}$, Naomi Schlesinger ${ }^{2}$, Sanders Clark ${ }^{3}$, Theresa Arndt ${ }^{3}$, Peter Lipsky ${ }^{4} .{ }^{1}$ University of Florida, Gainesville, United States of America; ${ }^{2}$ Rutgers Robert Wood Johnson Medical School, New Brunswick, United States of America; ${ }^{3}$ HVH Precision Analytics, LLC., Wayne, United States of America; ${ }^{4}$ RILITE Research Institute, Charlottesville, United States of America

Background: Gout is one of the most common inflammatory arthropathies. Despite available urate lowering therapies (ULT), many patients progress to chronic or advanced gout, characterized by the development of tophi, chronic inflammatory arthritis, and other manifestations resulting from persistent urate deposition. While numerous guidelines exist for the management of gout, there is little information on the frequency of their implementation, especially in patients with advanced gout.

Objectives: To evaluate the real-world practice patterns in patients diagnosed with advanced gout using a large administrative claims database from the United States. 
Methods: We carried out a retrospective analysis of the Symphony Integrated Dataverse to identify patients with advanced gout over an approximately 6-year period from October 2012 to August 2018. Patients were identified as having advanced gout if they were $>18$ years of age and had at least two medical claims for the diagnosis of gout on different days, separated by at least 3 months. Patients with advanced gout were identified and stratified based on their diagnosis as either chronic gout (ICD-9 274.02, 274.03, ICD-10 M1A.x) or tophaceous gout (ICD-9 274.03, 274.81 , 274.82, ICD-10 M1A.xxx1). A third category designated "uncontrolled gout" was clinically defined as any patient with at least three primary diagnoses of idiopathic gout (ICD-10 M10.0x, M1A.0x) along with at least three urate tests (CPT 84550, 84560). Percent and frequency of urate testing, rheumatology specialist visits, and administration of ULT (allopurinol, febuxostat, probenecid, and lesinurad) were evaluated for each diagnostic group.

Results: We identified 191,097 advanced gout patients, including 177,610 $(93 \%)$ with chronic gout, 31,475 (16.5\%) with tophaceous gout, and $20,943(11 \%)$ with uncontrolled gout. $35,992(18.8 \%)$ were coded in more than 1 diagnostic category. The median age was 67 (range: 19-80), $24.7 \%$ were female and $75.3 \%$ male, with an average of 5.4 years of claims history in the database. As shown in Tables 1 and 2, despite the diagnosis of advanced gout, urate testing, rheumatology consults, and ULT were inconsistent. Urate testing was definitional for uncontrolled gout patients, but was done in less than $65 \%$ of patients with the diagnosis of chronic or tophaceous gout and then less than once per year. Similarly, less than $60 \%$ of subjects with advanced gout received care by a rheumatologist and less than $80 \%$ received ULT and for less than $50 \%$ of the year.

Table 1. Percentage of patients with urate testing, rheumatologist visits, and urate lowering therapy

\begin{tabular}{|c|c|c|c|c|c|}
\hline Population & $\mathrm{N}$ & $\begin{array}{l}\text { Urate testing } \\
\text { (\% of } \\
\text { patients) }\end{array}$ & \multicolumn{2}{|c|}{$\begin{array}{c}\text { Rheumatologist visit (\% of } \\
\text { patients) }\end{array}$} & $\begin{array}{l}\mathrm{ULT}^{+} \\
\text {(\% of } \\
\text { patients) }\end{array}$ \\
\hline Chronic Gout & 177,610 & $61.72 \%$ & & $34.32 \%$ & $76.54 \%$ \\
\hline $\begin{array}{l}\text { Tophaceous } \\
\text { Gout }\end{array}$ & 31,475 & $63.74 \%$ & & $57.86 \%$ & $76.98 \%$ \\
\hline $\begin{array}{l}\text { Gout } \\
\text { Uncontrolled } \\
\text { Gout }\end{array}$ & 20,943 & $100.00 \% *$ & & $59.57 \%$ & $81.32 \%$ \\
\hline \multicolumn{6}{|c|}{$\begin{array}{l}{ }^{+} \text {Urate lowering therapies } \\
{ }^{*} \text { Definitional }\end{array}$} \\
\hline \multicolumn{6}{|c|}{$\begin{array}{l}\text { Table 2. Frequency of urate testing, rheumatologist visits, and urate lowering therapy } \\
\text { in advanced gout }\end{array}$} \\
\hline Population & $\mathrm{N}$ & $\begin{array}{l}\text { Mean } \\
\text { urate } \\
\text { tests/ } \\
\text { year }\end{array}$ & $\begin{array}{l}\text { ton } \\
\text { tologist } \\
\text { /year }\end{array}$ & $\begin{array}{l}\text { Mean } \mathrm{ULT}^{+} \\
\text {prescriptions } \\
\text { per patient }\end{array}$ & $\begin{array}{l}\text { Mean days with } \\
\text { active ULT } \\
\text { prescriptions/year }\end{array}$ \\
\hline Chronic Gout & 177,610 & 0.73 & 00 & 7.5 & 160.27 \\
\hline $\begin{array}{l}\text { Tophaceous } \\
\text { Gout }\end{array}$ & 31,475 & 0.98 & 72 & 9 & 160.14 \\
\hline $\begin{array}{l}\text { Uncontrolled } \\
\text { Gout }\end{array}$ & 20,943 & $2.25^{*}$ & 18 & 7.1 & 169.36 \\
\hline
\end{tabular}

\section{+Urate lowering therapies}

*Definitional

Conclusion: The subset of patients with advanced gout, identified either as chronic, tophaceous or uncontrolled, received suboptimal care compared to current guidelines. As this group of advanced gout patients is the most affected by urate deposition, added attention should be paid to optimizing their care.

Disclosure of Interests: N. Lawrence Edwards Consultant for: Horizon Pharma, Astra Zeneca, Selecta Biosciences, Naomi Schlesinger Consultant for: Astra Zeneca, Novartis, Horizon Pharma, Sanders Clark : None declared, Theresa Arndt: None declared, Peter Lipsky Consultant for: Consulting fees from Horizon Pharma

DOI: 10.1136/annrheumdis-2019-eular.6247

\section{SAT0436 CROWNED-DENS SYNDROME: A RECENT CASE SERIES IN A SINGLE CENTRE IN THE UNITED KINGDOM}

Jianfei Ma, Rania Gonem, Elliott Lever, Richard Stratton, Animesh Singh. Royal free hospital, Rheumatology, London, United Kingdom

Background: The crowned dens syndrome is a rare presentation of Calcium pyrophosphate deposition disease. It is characterised by severe acute or recurrent neck pain associated with headache, fever and elevated inflammatory markers. CT usually demonstrates calcium pyrophosphate crystal deposition in the suspensory ligaments adjacent to the atlanto-axial joint. We are reporting a series of four patients presenting with sudden onset of neck pain and raised inflammatory makers over a 9 month period.

Objectives: To raise awareness of crowned-dens syndrome, its clinical presentation, radiographic findings and management.

Methods: Four patients' electronic patient records including history, clinical findings and treatment were reviewed. Imaging was discussed at a rheu matology/radiology multi-disciplinary meeting.

Results: Four patients (2 female, 2 male) aged between 64 and 86 years presented with severe neck pain and stiffness. In all cases the onset of symptoms was less than a week prior to presentation and was associated with greatly restricted mobility. 2 patients had associated head ache, arthralgia and myalgia. All patients had normal tone, power, reflexes and sensation on neurological examination. There was no pyrexia. Inflammatory markers were markedly raised with CRP ranging from 90-343 $\mathrm{mg} / \mathrm{L}$ at presentation (Table 1). One patient had a neutrophilia CT scan of the head was performed in each case and showed no evidence of subarachnoid haemorrhage, space occupying lesion or meningeal enhancement. PET-CT scan in all patients showed intense uptake around the atlanto-axial joint as well as calcification of the ligaments. All patients were commenced on a reducing regime of prednisolone starting at $40 \mathrm{mg}$ daily, tapering to $0 \mathrm{mg}$ over 6 weeks. Symptoms and inflammatory markers reduced on induction of steroids. Two patients suffered a relapse on reducing steroids and required further higher doses of steroid.

Table 1. Patient demographics

\begin{tabular}{lcccc}
\hline Patient & $\begin{array}{c}\text { Age } \\
(\text { Years })\end{array}$ & Gender & $\begin{array}{c}\text { CRP on presentation }(\mathrm{mg} / \\
\text { L) }\end{array}$ & $\begin{array}{c}\text { ESR on presentation }(\mathrm{mm} / \\
\mathrm{Hr})\end{array}$ \\
\hline 1 & 64 & Male & 90 & 77 \\
2 & 74 & Male & 247 & - \\
3 & 81 & Female & 133 & 120 \\
4 & 86 & Female & 343 & 112 \\
\hline
\end{tabular}

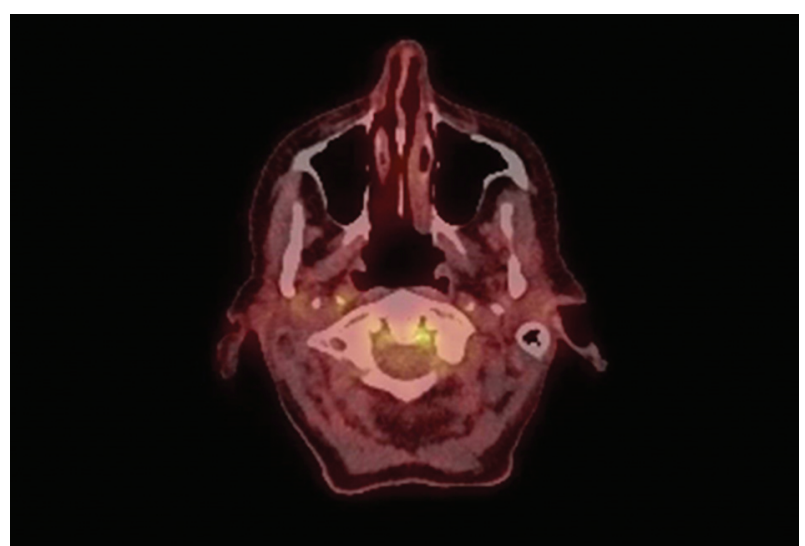

Figure 1. Image from PET-CT scan of Patient 4 showing increased tracer uptake around the odontoid peg (arrow)

Conclusion: Patients presenting with acute neck pain, headache and raised inflammatory markers require evaluation for an infective aetiology. Pyrophosphate disease of the atlanto-axial joint however, appears to be an increasingly recognised cause of this presentation. Awareness by acute physicians, rheumatologists and radiology colleagues is important as the condition can be misdiagnosed as Giant Cell Arteritis, Polymyalgia Rheumatica or meningitis; in order to avoid unnecessary investigations and delay in initiating the appropriate treatment. The condition is steroid responsive.

\section{REFERENCES}

[1] Heck A, Nolan N, Rojas-Moreno C, Crowned Dens Syndrome: Calcium Pyrophosphate Deposition Disease Masquerading as Osteomyelitis. J Rheumatol. 2018 Oct;45(10):1422-1423 